\title{
PEREMPUAN DAN KEPEMIMPINAN DALAM PENDIDIKAN ISLAM
}

\author{
Isyatul Mardiyati \\ Fakultas Tarbiyah dan Ilmu Keguruan (FTIK) \\ Institut Agama Islam Negeri (IAIN) Pontianak
}

\begin{abstract}
The discourse of woman leadership in Islamic Education, in terms of religious concept, is still contemporarily hegemonized in a leadership structure at religious-based university. Moreover, at this point, every analysis has a significant argument which ends to gender deconstruction, whether it is possible for woman to perform leadership in an education institution. Besides, it also conveys the legalization of important person in the institution, rector at Islamic University, for instance, as well as Minister of Religion. Therefore, the article densely discusses woman and leadership in Islamic education.
\end{abstract}

\section{Keywords:}

Leadership, Islamic Education

\section{PENDAHULUAN}

Allah SWT telah menciptakan manusia dengan sebaik-baiknya bentuk ${ }^{27}$, baik itu wujud untuk laki-laki maupun untuk perempuan, keduanya semata-mata tercipta adalah untuk beribadah serta mendarma baktikan dirinya hanya kepada Allah SWT ${ }^{28}$. Islam dalam hal ini tidak hanya merupakan ajaran yang bersifat teknis mengatur hubungan manusia melalui ritual peribadatannya, melainkan juga turut mengatur hubungan sosial manusia kepada Allah SWT dan kepada sesama manusia lainnya (bablum minallah wa hablum minannas), sehingga tidak mengherankan Islam muncul sebagai agama penyempurna yang mengajarkan manusia pada konsep kesamaan derajat tanpa ada diskriminasi antara jenis kelamin laki-laki dan perempuan, sehingga kalaupun ada perbedaan antara laki-laki dan perempuan dalam kacamata agama, hal ini lebih kepada persoalan ketaqwaannya di hadapan Allah SWT, sebagaimana firman-Nya, dalam Al-Qur'an yang artinya :

Hai manusia, sesungguhnya Kami menciptakan kamu dari seorang laki-laki dan seorang perempuan dan menjadikan kamu berbangsa-bangsa dan bersuku-suku supaya kamu saling kenal mengenal. Sesungguhnya orang yang paling mulia di antara kamu di sisi Allah ialah orang yang paling bertakwa di antara kamu. Sesungguhnya Allah Maha Mengetahui lagi Maha Mengenal. (Al-Hujuraat (49): 13)

Dari ayat tersebut, Islam pada hakekatnya tidak membedakan antara laki-laki dan perempuan, baik dalam hal kedudukan, harkat, martabat, kemampuan, dan kesempatannya untuk berkarya. Setiap mahluk bagi laki-laki dan perempuan keduanya telah memiliki fungsi dan perannya masing-masing, dari fungsi dan perannya tersebut laki-laki dan perempuan semestinya dapat saling mengisi dan melengkapi, sehingga suatu hal yang tidak dapat dipungkiri bahwa perempuan merupakan bagian integral dari suatu masyarakat begitu pula halnya dengan laki-laki.

Secara biologis memang perbedaan jenis kelamin perempuan dan laki-laki dapat terlihat jelas, tetapi dari segi hak dan kewajibannya sebagai manusia, hal ini adalah sama, dengan demikian keberadaan perempuan tidak dapat dipandang sebelah mata, hanya sebagai obyek kebutuhan

${ }^{27}$ Lihat, Al-Qur'an, QS. At-Tiin (95): 4, artinya: Sesungguhnya Kami telah menciptakan manusia dalam bentuk yang sebaik-baiknya.

${ }^{28}$ Lihat, Al-Qur'an, QS QS Adz Dzaariyat (51): 56, artinya : Dan Aku tidak menciptakan jin dan manusia melainkan supaya mereka menyembah-Ku. 
biologis laki-laki, melainkan merupakan mitra yang sejajar yang saling melengkapi dalam berbagai aspek kehidupan, baik yang bersifat domestik maupun publik.

Fenomena yang sering kali muncul di masyarakat seringkali tidak sesuai dengan pernyataan di atas, bahkan dalam dunia pendidikan Islam khususnya di perguruan tinggi agama sepertinya hampir tidak memungkinkan celah adanya calon ketua Sekolah Tinggi Agama maupun rektor di Institut Agama yang berasal dari jenis kelamin perempuan. Bahkan dalam sajarah politik kenegaraan di Indonesia sejak merdeka sampai tulisan ini disusun pada akhir tahun 2014, belum pernah ada menteri agama Republik Indonesia (RI) yang berasal dari kalangan kelamin perempuan, meskipun negara ini pada tahun 2001 - 2004 pernah dipimpin oleh seorang presiden perempuan pertama yakni, Megawati Sukarnoputri.

Selain itu, tidak dapat dipungkiri sudah banyak kepala sekolah di tingkat madrasah maupun para pejabat yang duduk di perguruan tinggi berasal dari kaum perempuan, namun khusus di perguruan tinggi Islam keberadaan mereka biasanya hanya sebatas pada tingkat sekretaris jurusan, dekan, wakil ketua, wakil rektor atau direktur Pasca Sarjana dan belum menjadi pejabat tinggi sebagaimana terjadi di Kementerian Pendidikan yang dalam sejarahnya telah mencatat beberapa perempuan yang telah dan sedang menjabat sebagai rektor, semisal Prof. Hj. Asniar Ismail, SE, MM seorang Rektor Universitas Tanjungpura periode 2003-2007 yang dilantik oleh Mendiknas RI A. Malik Fajar ketika itu ataupun Prof. Dr. Dwia Aries Tina, MA yang terpilih sebagai Rektor Universitas Hasanuddin Periode 2014-2018. Hal inilah yang menjadi kendala terjadinya bias gender dari diskriminasi dan ketidakadilan terhadap perempuan. Filosofi Jawa bahkan menyebutkan perempuan hanya sebagai 'konco wingking' yang tugasnya sebatas persoalan dapur, anak dan kasur. Anggapan tersebut belum lagi diperkuat oleh penafsiran-penafsiran yang bias dan dan sarat dengan kepentingan kaum yang tidak menghendaki kemitraan antara laki-laki dan perempuan. Dari sinilah penulis mengambil tema tentang perempuan dan kepemimpinan dalam pendidikan Islam.

\section{KESETARAAN GENDER DALAM KONSEP KEPEMIMPINAN ISLAM}

Gender merupakan hasil konstruksi sosial budaya dan dapat berubah sesuai dengan perkembangan zaman. Peran gender bersifat dinamis, dipengaruhi oleh umur (generasi tua dan muda, dewasa dan anak-anak), ras, etnik, agama, lingkungan geografi, pendidikan, sosial ekonomi dan politik. Oleh karena itu, perubahan peran gender sering terjadi sebagai respon terhadap perubahan kondisi sosial ekonomi, budaya, sumber daya alam dan politik termasuk perubahan yang diakibatkan oleh upaya-upaya pembangunan atau penyesuaian program struktural (structural adjustmentprogram) maupun pengaruh dari kekuatan-kekuatan di tingkat nasional dan global, dengan demikian, dari dua pengertian tersebut dapat disimpulkan bahwa gender merupakan indentifikasi perbedaan antara laki-laki dan perempuan dari segi-segi sosial budaya, psikologis dan bidang lainnya. Sehingga dalam persoalan gender itu sendiri selalu berkaitan dengan persamaan hak antara laki-laki dan perempuan.

Ketidakadilan gender ini biasanya bermula dari kesenjangan gender dalam berbagai aspek kehidupan, terutama dalam akses pendidikan dan sumber ekonomi. Hal ini karena adanya stereotype bahwa perempuan lemah, dan hanya bisa menerima. Karena adanya mitos bahwa sperma sebagai sumber kehidupan dan perempuan hanya mampu menerima saja. Ketidakadilan gender pada lansia perempuan termanifestasi dalam bentuk stereotype, subordinasi, marginalisasi, peran ganda dan kekerasan. Manifestasi ketidakadilan ini saling melengkapi dan tidak dapat dipisahkan. Stereotype adalah suatu konsep yang berkaitan dengan konsep peran, tetapi berbeda. Stereotipe dapat dilukiskan sebagai 'gambaran kepala kita' dan terdiri dari sejumlah sifat dan harapan yang berlaku bagi suatu kelompok. Dapat saja gambaran tersebut tidak akurat karena stereotipe merupakan suatu generalisasi tentang sifat-sifat yang dianggap dimiliki oleh orang-orang tertentu tanpa perlu didukung oleh fakta objektif, misalnya anggapan bahwa perempuan lemah, emosional, bertugas sebagai ibu rumah tangga, dan lain-lain. Stereotipe memberi arah pada perilaku seseorang karena sering kali menentukan cara seorang memandang suatu kelompok, atau cara seorang berinteraksi dengan orang lain. 
Berkaitan dengan fungsi gender dalam kepemimpinan, dalam hal ini kepemimpinan merupakan kegiatan untuk mempengaruhi orang-orang yang kemudian diarahkan terhadap pencapaian tujuan organisasi. Sutisna (1993) merumuskan kepemimpinan sebagai proses mempengaruhi kegiatan seseorang/kelompok dalam usaha ke arah pencapaian tujuan dalam situasi tertentu. Sementara Soepardi (1988) mendefinisikan kepemimpinan sebagai kemampuan untuk menggerakkan, mempengaruhi, memotivasi, mengajak, mengarahkan, menasehati dengan maksud agar manusia sebagai media manajemen mau bekerja dalam rangka mencapai tujuan administrasi secara efektif dan efisien ${ }^{29}$.

Dalam Islam, setiap manusia pada hakikatnya adalah pemimpin baik bagi dirinya sendiri maupun apa yang dipimpinnya, sehingga seorang pemimpin suatu saat akan dimintai pertanggungjawabannya. Hal ini sebagaimana hadits yang berasal dari Rasulullah SAW yang diriwayatkan oleh Ibnu Umar r.a :

Saya telah mendengar Rasulullah SAW bersabda : setiap orang adalah pemimpin dan akan diminta pertanggungjawaban atas kepemimpinannnya. Seorang kepala negara akan diminta pertanggung jawaban perihal rakyat yang dipimpinnya. Seorang suami akan ditanya perihal keluarga yang dipimpinnya. Seorang isteri yang memelihara rumah tangga suaminya akan ditanya perihal tanggungjawab dan tugasnya. Bahkan seorang pembantu/ pekerja rumah tangga yang bertugas memelihara barang milik majikannya juga akan ditanya dari hal yang dipimpinnya. Dan kamu sekalian pemimpin dan akan ditanya (diminta pertanggungan jawab) dari hal hal yang dipimpinnya.

Dari hadits tersebut pada dasarnya, manusia baik itu laki-laki maupun perempuan adalah seorang pemimpin, dan pokok dari suatu kepemimpinan dalam Islam adalah tanggunjawab, dan tanggung jawab terkecil yang dipikul seseorang dalam hidupnya sekurang-kurangnya adalah dirinya sendiri. Akan tetapi, tanggung jawab di sini bukan semata-mata bermakna melaksanakan tugastugas pokoknya lalu tidak menyisakan dampak (atsar) bagi yang dipimpin. Melainkan lebih dari itu, yang dimaksud tanggung jawab di sini lebih kepada mewujudkan kesejahteraan dan kebaikan bagi apa yang dipimpinnya atau sebuah kebijakan dan tindakan seorang pemimpin haruslah terkait langsung kepada kesejahteraan apa yang dipimpinnya (tasharruf al-imâm 'alâ al-ra'iyyah manûthun bi almashlabab)". Sebagai contoh, jika orang tua hanya sekedar memberi makan anak-anaknya tetapi tidak memenuhi standar gizi serta kebutuhan pendidikannya, maka hal itu masih jauh dari makna tanggung jawab yang sebenarnya, yang dalam hal ini orang tua tidak hanya memberikan makan, namun ia juga hendaknya mampu mengarahkan anaknya kepada kehidupan yang lebih baik sesuai dengan ajaran agama.

Kepemimpinan seorang perempuan dalam Islam di Indonesia khususnya dalam dunia pendidikan, tidak terjadi begitu saja. Perjuangan para tokoh perempuan semisal Raden Ayu Kartini, Maria Ulfa Anshor, Dita Indah Sari dan lain-lain, telah membuka celah terciptanya harmonisasi kemitraan kaum laki-laki dan perempuan dalam pendidikan, pekerjaan maupun kehidupan. Namun pada sisi lain kiprah perempuan tersebut tidak serta merta menghilangkan peran dan fungsi yang fundamental, yakni perannya sebagai ibu untuk melahirkan, menyusui, dan menjadi guru pertama bagi anak-anaknya. Dari keseimbangan tersebut diharapkan akan tercipta kehidupan antara lakilaki dan perempuan yang baik dan tidak memunculkan persoalan yang baru setelah pudarnya persoalan gender.

Lebih lanjut, berkaitan dengan kepemimpinan pendidikan dalam Islam, para ulama memiliki perbedaan pendapat, khususnya berkaitan dengan boleh atau tidaknya perempuan menjadi pemimpin. Hal ini disebabkan oleh adanya kalimat 'arrijal qawwamun ala an-nisa' di dalam al-Qur'an surat An-nisa : 34 yang secara normatif menunujukkan superioritas laki-laki dibandingkan perempuan. Kalimat ini juga sering diartikan bahwa kewajiban menjadi seorang

${ }^{29}$ E. Mulyasa, Manajemen Berbasis Sekolah, (Bandung: Remaja Rosdakarya, 2004), hal. 107 
pemimpin adalah hanya untuk kaum laki-laki saja, sedangkan perempuan adalah orang yang harus dipimpin.

Memang jika diperhatikan sepintas, kata qawwam dalam surah surat An-nisa : 34 berarti pemimpin, pelindung, pengatur, dan lain-lain. Hal ini tidak terlepas dari keunggulan kaum laki-laki secara fisik maupun fisikis mereka jika dibandingkan dengan perempuan, bahkan al-Zamakhsari dalam Tafsir al-Kasysyaf mengungkapkan keunggulan laki-laki atas perempuan adalah karena akal, ketegasan, tekad yang kuat, kekuatan fisik, secara umum memilki kemampuan baca tulis, dan keberanian. Thaba'thaba'i mengungkapkan kelebihan laki-laki disebabkan oleh akalnya saja mampu melahirkan jiwa-jiwa seperti keberanian, kekuatan, dan kemampuan dalam mengatasi kesulitan. Sebaliknya, perempuan lebih sensitif dan emosional ${ }^{30}$.

Berdasarkan hal tersebut, maka tidak mengherankan bahwa tugas-tugas berat termasuk kepemimpinan sebenarnya hanya layak untuk diemban oleh kaum laki-laki, sebagaimana para utusan Allah SWT yakni para nabi dan rasul yang kesemuanya adalah laki-laki. Demikian juga halnya dalam mengkumandangkan suara adzan pada saat shalat ataupun khutbah Jum'at ataupun shalat idul fitri dan idul adha yang semakin mempertegas otoritas dan superioritas kaum laki-laki jika dibandingkan dengan kaum perempuan.

Jika melihat teks dan implementasi ayat tersebut, penafsiran tekstual terhadap surat Annisa ayat 34 memang benar adanya, serta merupakan isyarat bahwa perempuan bukanlah seorang pemimpin, namun terkadang suatu konsep penafsiran akan sangat dipengaruhi oleh latar belakang penafsir dan situasi iklim politik pada saat itu. Apa lagi hal ini berkaitan dengan sisi feminin dan maskulin sesorang untuk menjadi pemimpin dan bukan terletak pada jenis kelaminnya.

Masih ingat dalam benak kita, peristiwa perang Jamal atau perang Unta yang terjadi pada 11 Jumadil Akhir tahun 36 Hijriah antara khalifah Ali bin Abi Thalib melawan seorang panglima perang perempuan yang bernama Aisyah binti Abu Bakar ash-Shiddiq. Begitu juga dengan Ratu Balqis seorang pemimpin bagi kaumnya yang sempat berseteru dengan Nabi Sulaiman, maupun perempuan dari kalangan sufi bernama Rabi'ah al Adawiyyah yang dijuluki The Mother of the Grand Master atau Ibu Para Sufi Besar karena kezuhudannya. Puisi-puisinya tentang cinta (mababbah) telah memberikan inspirasi kepada para sufi lain sepanjang sejarah. Hal ini sepertinya sedikit banyak bertentangan dengan pemaknaan surat An-nisa ayat 34 yang menempatkan hanya laki-laki saja yang dapat menjadi pemimpin.

Lebih lanjut, kepemimpinan tidak sebatas pada kekuatan fisik dan sifat-sifat maskulin yang ada pada diri seseorang berdasarkan jenis kelamin. Namun lebih dari itu, kepemimpinan adalah kemampuan seseorang dalam mengemban tugas-tugas yang dibebankan kepadanya, suatu nilai yang dianggap paling dominan dibandingkan hanya ditinjau dari perbedaan jenis kelamin. Sebuah kualitas kepribadian yang meliputi kemampuan (ability), kecakapan (capacity), kesanggupan (faculty), dan kepandaian (skill) dalam berfikir, bertindak serta melakukan umpan balik terhadap suatu permasalahan. Hal inilah yang sebenarnya disampaikan Islam terkait hubungan antara laki-laki dan perempuan dan kepemimpinan. Sebuah konsep kemitraan yang sejajar serta saling mengisi satu dengan yang lain agar dapat mengenal siapa dirinya dan orang lain ${ }^{31}$. Dengan demikian, tidak diragukan lagi dorongan ke arah kesetaraan laki-laki dan perempuan dalam konteks kepemimpinan sebenarnya sebuah konsep saling mengisi yang tidak menjadikan perbedaan biologis menimbulkan ketidaksetaraan dalam kehidupan. Fungsi-fungsi biologis harus dibedakan dari fungsi-fungsi sosial, ibadah dan hak untuk mendapatkan kesejahteraan hidup.

${ }^{30}$ M. AI-Fatih Suryadilaga, "Kepemimpinan Perempuan Sebagai Imam Shalat" dalam Hamim Ilyas, Perempuan Tertindas? Kajian Hadis Misoginis (Yogyakarta: TP, 2003), hal. 270.

${ }^{31}$ Lihat, Al-Qur'an, QS. Al-Hujuraat (49): 13, yang artinya: Hai manusia, sesungguhnya Kami menciptakan kamu dari seorang laki-laki dan seorang perempuan dan menjadikan kamu berbangsa-bangsa dan bersuku-suku supaya kamu saling kenal mengenal. Sesungguhnya orang yang paling mulia di antara kamu di sisi Allah ialah orang yang paling bertakwa di antara kamu. Sesungguhnya Allah Maha Mengetahui lagi Maha Mengenal. 


\section{PEMIMPIN PENDIDIKAN DARI KAUM PEREMPUAN}

Pemimpin pendidikan dari kalangan perempuan dalam sejarah peradaban Islam, bukanlah merupakan hal yang baru, sebagaimana Aisyah binti Abu Bakar ash-Shiddiq yang memegang posisi penting sebagai pemberi fatwa semenjak Rasulullah SAW wafat. Ia adalah pendidik perempuan yang dari lisannya banyak diperoleh informasi maupun hadits yang berasal dari Rasulullah SAW, sehingga kemudian Aisyah menjadi sumber rujukan umat Islam hampir dalam setiap persoalan hingga pada akhirnya beliau wafat. Setiap kali terjadi perselisihan pendapat diantara ulama, Aisyahlah yang mereka tuju untuk menghakimi persoalan itu. Lebih dari itu, upaya-upaya yang dilakukan Aisyah dalam membimbing umat Islam tidaklah bisa dipandang sebelah mata. Hal ini tidak kalah penting dibandingkan dengan apa yang dilakukan oleh para sahabat yang lain yang tentu secara biologis berbeda.

Islam juga mencatat seorang perempuan bernama Ummu Salamah bint Abi Umayyah, Hafshah bint Umar, Asma bint Abu Bakar, Ramlah bint Abi Sufyan, Fatimah bint Qais yang juga menjadi rujukan para sahabat dalam beberapa persoalan hukum dan fatwa, terutama persoalan yang berkaitan dengan wanita. Mereka adalah guru besar bagi kaum perempuan juga bagi kaum laki-laki. Mereka biasa berdiskusi dan berdebat secara terbuka dengan ulama laki-laki dalam banyak aspek dan untuk menyelesaikan problema kehidupan umat pada masanya. Belum lagi Sayyidah Nafisa seorang guru dari ulama besar setaraf Imam Syafi'i, maupun Ibnu 'Arabî juga berguru pada tiga orang perempuan cerdas dan alim di Makkah : Sayyidah Nizam, Fakhr al Nisa dan Qurrah al 'Ain.

Para perempuan ini memang dapat digolongkan sebagai "pemimpin pendidikan tradisional" karena pada umumnya telah mengisi kedudukan kepemimpinan berdasarkan garis keturunan maupun kedekatannya dengan sumber belajar ${ }^{32}$, namun bagaimanapun juga dari kehadiran dan peran mereka inilah Islam yang pada awalnya hanya berkutat di jazirah Arab dapat berkembang seperti sekarang ini, atau dengan kata lain jenis kelamin tidak dapat menjadi ukuran apakah seseorang bisa mengisi jabatan kepemimpinan khususnya kepemimpinan dalam pendidikan.

Selanjutnya, nama-nama ulama atau dalam hal ini pemimpin pendidikan yang berasal dari perempuan melekat hampir pada seluruh ibu yang ada di dunia, dimana hal sudah berlangsung ketika bayi masih di dalam kandungannya. Apa yang seorang ibu dengarkan atau bacakan kepada bayi dalam kandungan, maka hal tersebut itu pula akan didengar oleh sang bayi. Emosional dan watak seorang ibu pun dapat ditularkan melalui perilaku seorang ibu selama mengandung dan mengasuh. Lebih dari itu, peran seorang ibu dalam pendidikan anaknya merupakan sifat keteladanan, pada usia awal perkembangan anak biasanya meneladani apa saja yang berlaku pada orang-orang terdekatnya pada saat ini suka menolong orang lain, suka membaca, belajar, berbicara sopan dan lain-lain. Ataukah justru melakukan hal-hal yang bertentangan dengan yang telah tersebut hal ini akan bergantung pada yang menjadi teladannya. Allah SWT berfirman, yang artinya:

Dan Allah mengeluarkan kamu dari perut ibumu dalam keadaan tidak mengetahui sesuatu pun, dan Dia memberi kamu pendengaran, penglihatan dan hati, agar kamu bersyukur (QS. An Nahl (16): 78).

Melalui berbagai penjelasan di atas, maka tidak heran dalam kepemimpinan pendidikan dapat dikatakan bahwa perempuan berada dalam posisi berbeda dengan laki-laki, namun setara. Kepemimpinan dalam pendidikan bukanlah sebatas pelaksanaan ibadah shalat jum'at, dimana dari muadzin sampai pemberi khutbah haruslah berasal dari laki-laki. Sebab kepemimpinan dalam pendidikan adalah cara atau usaha dalam mempengaruhi, mendorong, membimbing, mengarahkan, dan menggerakkan guru, staf, siswa, orang tua siswa, dan pihak lain yang terkait,

32 Saparindah dan Imelda Bachtiar, Berbeda tapi Setara: Pemikiran Tentang Kajian Perempuan (Jakarta: Buku Kompas, 2010). Hal. 207. 
untuk bekerja/berperan serta guna mencapai tujuan yang telah ditetapkan. Maksudnya bagaimana cara pemimpin untuk membuat orang lain bekerja untuk mencapai tujuan pendidikan.

Selanjutnya, adapun yang menjadi prinsip-prinsip kepemimpinan dalam pendidikan yang secara umum berlaku, yaitu:

1. Konstruktif, artinya pemimpin harus mendorong dan membina setiap staf untuk berkembang secara optimal

2. Kreatif, artinya pemimpin harus selalu mencari gagasan dan cara baru dalam melaksanakan tugasnya

3. Partisipatif, artinya mendorong keterlibatan semua pihak yang terkait dalam setiap kegiatan pendidikan

4. Kooperatif, artinya mementingkan kerja sama dengan staf dan pihak lain yang terkait dalam melaksanakan setiap kegiatan

5. Delagatif, artinya berupaya mendelegasikan tugas kepada staf, sesuai dengan deskripsi tugas/jabatan serta kemampuan mereka

6. Integratif, artinya selalu mengintegrasikan semua kegiatan, sehingga dihasilkan sinergi untuk mencapai tujuan sosial

7. Rasional dan obyektif, artinya dalam melaksanakan tugas atau bertindak selalu berdasarkan kepentingan rasio dan obyektif

8. Pragmatis, artinya dalam menetapkan kebijakan atau target, pemimpin harus mendasarkan pada kondisi dan kemampuan nyata yang dimiliki lembaga yang ia pimpin

9. Keteladanan, artinya dalam memimpin, seorang pemimpin harus dapat menjadi contoh yang baik

10. Adaptabel dan fleksibel, artinya pemimpin harus dapar beradaptasi dan fleksibel dalam manghadapi situasi baru dan juga menciptakan situasi kerja yang memudahkan staf untuk beradaptasi ${ }^{33}$.

Perilaku sebagaimana dijelaskan di atas sebenarnya adalah sifat-sifat yang dapat dipelajari untuk meningkatkan aktivitas organisasi sesuai dengan peran yang diharapkan masyarakat terhadap jenis kelamin tertentu. Di sini budaya masyarakat akan berpengaruh terhadap peran jenis kelamin seseorang serta implikasinya terhadap suatu perubahan. Ada karaktristik kepribadian, tugas pekerjaan, dan kegiatan yang dianggap wajar bagi laki-laki dan lainnya wajar bagi perempuan, tinggal bagaimana laki-laki dan perempuan memposisikan dirinya sesuai kodrat dan selama tidak bertentangan dengan ajaran agama.

\section{PENUTUP}

Isu gender masih menjadi bahasan analisis sosial dan trend wacana perdebatan mengenai pembangunan dan perubahan sosial. Bahkan, ruang lingkup kajian ini sudah meretas ke seluruh sektor yang ada, diantaranya : hukum, sosial, budaya, ekonomi, politik, pendidikan, kesehatan dan keagamaan. Ketidakadilan, sehingga gender sering kali dipersoalkan karena secara sosial problematika ini telah melahirkan perbedaan peran, tanggung jawab, hak dan fungsi serta ruang aktivitas laki-laki dibandingkan perempuan. Perbedaan tersebut akhirnya membuat masyarakat cenderung diskriminatif dan pilih-pilih tentang perlakuan, akses, partisipasi, serta kontrol dalam hasil pembangunan laki-laki dan perempuan.

Berkaitan dengan hal tersebut, banyak pendapat yang berkembang mengenai kepemimpinan pendidikan yang dilakukan oleh kaum perempuan dalam wacana pemikiran Islam klasik dan sangat terpengaruh oleh budaya dan pemahaman yang bersifat patriarkhi, sehingga tidak heran jika produk pemikiran yang ada masih berpihak pada kepentingan laki-laki. Perempuan masa kini memiliki memang kesempatan yang luas untuk berkiprah dalam segala bidang, termasuk untuk menjadi pemimpin dalam pendidikan. Hal ini sama sekali tidak bertentangan dengan ajaran Islam karena al-Qur'an tidak membedakan manusia kecuali dalam amal ibadahnya. Untuk itulah, dimasa yang

${ }^{33}$ Suryo Subroto, Manajemen Pendidikan di Sekolah, Edisi Revisi, (Jakarta: PT Asdi Mahasatya, 2004), hal 187. 
akan datang diharapkan ke depan akan muncul pemimpin pendidikan yang berasal dari perempuan terutama pada tingkat perguruan tinggi Islam.***

\section{REFERENSI}

Abdullah, Sufyan Raji. 2006. Mengenai Aliran-Aliran dalam Islam dan Ciri-Ciri Ajarannya. Jakarta: Pustaka Al Riyadh.

Depag RI, 1975/1976. Al-Qur'an dan Terjemahannya. Jakarta: PT. Bumi Restu Jaya.

E. Mulyasa. 2004. Manajemen Berbasis Sekolah. Bandung: Remaja Rosdakarya

Kuntjaraningrat. 1984. Kebudayaan Jawa. Jakarta: Balai Pustaka.

M. AI-Fatih Suryadilaga. 2003. "Kepemimpinan Perempuan Sebagai Imam Shalat" dalam Hamim Ilyas, Perempuan Tertindas? Kajian Hadis Misoginis. Yogyakarta: TP

Saparindah dan Imelda Bachtiar. 2010. Berbeda tapi Setara: Pemikiran Tentang Kajian Perempuan. Jakarta: Buku Kompas.

Sholihan. 2008. Modernitas, Postmodernitas \& Agama. Semarang: Walisongo Press.

Suryo Subroto. 2004. Manajemen Pendidikan di Sekolah, Edisi Revisi. Jakarta: PT Asdi Mahasatya.

Y. Al-Barry, M. Dahlan \& L. Lya Sofyan. 2003. Kamus Induk Istilah Imiah Surabaya: Target Press. 